Piotr Łaciak

Uniwersytet Śląski w Katowicach

ORCID: 0000-0002-3010-3743

e-mail: piotr.laciak@us.edu.pl

\title{
Rozjaśnienie sensu istnienia jako cel fenomenologii Husserla
}

Kluczem do zrozumienia sensu istnienia $\mathrm{w}$ fenomenologii Edmunda Husserla jest sformułowana przezeń teza bezpośrednio nawiązująca do filozofii Immanuela Kanta: „Bycie (Sein) nie jest realnym orzecznikiem"1․ W sensie fenomenologicznym teza ta oznacza, że możemy wykazać istnienie przedmiotu za pomocą deskryptywnej analizy sposobów jego dania, nie zaś przez odniesienie do obiektywnej rzeczywistości. Celem artykułu jest rozjaśnienie sensu tego, co istnieje rzeczywiście, w świetle tej tezy w dwóch punktach. Po pierwsze różnica między przedmiotem istniejącym rzeczywiście a przedmiotem „tylko intencjonalnym" nie jest różnicą realną, lecz różnicą co do sposobów dania. Po drugie pojęcie istnienia nie jest pojęciem pustym, dotyczącym wszelkich dziedzin bytowych, lecz różnicuje się odpowiednio do sposobów naocznego, dokładniej - spostrzeżeniowego dania, a zasadniczo odmienne charaktery istnienia, jakie należy przypisać światu i świadomości, są ugruntowane w odmiennych typach ich doświadczenia: $\mathrm{w}$ wypadku świata chodzi o nieadekwatne, presumpcyjne, przeświadczeniowe doświadczenie, a w odniesieniu do świadomości - doświadczenie apodyktycznie pewne (spostrzeżenie immanentne i przedrefleksyjne przeżywanie). Rezultat analiz zawartych $\mathrm{w}$ artykule jest następujący: o ile istnienie świata stanowi korelat zawartego w przeświadczeniowej

1 Edmund Husserl, Badania logiczne, t. 2, cz. 2: Badania dotyczace fenomenologii i teorii poznania, przeł. Janusz Sidorek (Warszawa: PWN, 2000), 163. 
(presumpcyjnej) pewności uznania go w bycie (Setzung), o tyle świadomość jest absolutną rzeczywistością i ustanawia się sama przez się w istnieniu.

\section{Kryłyka poznania jako warunek metafizyki w znaczeniu ostatecznej nauki o bycie}

Już w Badaniach logicznych, prezentujących przedtranscendentalny punkt widzenia, Husserl rozpoznaje paradoksalną sytuację filozofowania, która wymaga radykalnej zmiany namysłu, wytrącającej filozofa z trwania w naturalnej bezproblematyczności i bezrefleksyjności:

[Filozof - Piotr Łaciak] Powinien wszak wiedzieć też, że właśnie za tym, co „zrozumiałe samo przez się", kryją się najtrudniejsze problemy, i to w tak wielkim stopniu, że paradoksalnie, choć nie bez głębszego sensu, można filozofię nazwać nauką o tym, co trywialne. W każdym razie także tutaj to, co na pierwszy rzut oka tak trywialne, po głębszym rozpatrzeniu okazuje się źródłem głębokich i wielorako rozgałęzionych problemów².

Po zwrocie transcendentalnym twórca fenomenologii radykalizuje ten pogląd, mocno akcentując, że filozofowanie wymaga przeciwnego naturze ukierunkowania i ma doprowadzić do rzeczywistego rozjaśnienia tego, co w postawie naturalnej jawi się jako bezproblematyczne, rozjaśnienia domagającego się krytycznego rozpoznania wypływającej z nastawienia naturalnego samozrozumiałej naiwności oraz przezwyciężenia tej naiwności. W ten sposób fenomenologię transcendentalną można uznać za uniwersalną krytykę poznania, która stawia sobie za cel problematyzację wszelkich naturalnie zrozumiałych samo przez się prawd i uczynienie ich transcendentalnie zrozumiałymi, przy czym zagadką wszelkich zagadek, która wymaga transcendentalnego rozstrzygnięcia, okazuje się samozrozumiała, przeświadczeniowa pewność istnienia świata. W Kryzysie nauk europejskich Husserl pisze wprost:

Na początku fenomenolog żyje takim paradoksem, że to, co samo przez się zrozumiałe, musi widzieć jako problematyczne, jako zagadkowe oraz że odtąd nie może mieć żadnego innego problemu naukowego poza tym, by uniwersalną samą przez się zrozumiałość istnienia świata - która dla niego jest największą ze wszystkich zagadek - przemienić w zrozumiałość [rzeczywistą] ${ }^{3}$.

2 Edmund Husserl, Badania logiczne, t. 2, cz. 1: Badania dotyczace fenomenologii i teorii poznania, przeł. Janusz Sidorek (Warszawa: PWN, 2000), 427.

${ }^{3}$ Edmund Husserl, „Die Krisis der europäischen Wissenschaften und die transzendentale Phänomenologie. Eine Einleitung in die phänomenologische 
Z kolei w Idei fenomenologii czytamy: „Na początku krytyki poznania należy tedy opatrzyć wskaźnikiem proble ma ty czności cały świat, fizyczną i psychiczną przyrodę, w końcu także [nasze] własne ludzkie Ja, wraz ze wszystkimi naukami, które odnoszą się do tych przedmiotów. Ich byt, ich moc obowiązująca pozostają w zawieszeniu" ${ }^{4}$. Zaznaczmy dobitnie, że owo zawieszenie (epoché) ma charakter chwilowy i jest motywowane potrzebą transcendentalnego zrozumienia tego, co skrywa swój problematyczny charakter pod szatą naturalnej samozrozumiałości, to znaczy - potrzebą rozwiązania zagadki istnienia świata: „Trzeba najpierw stracić świat - argumentuje Husserl w Medytacjach kartezjańskich - poprzez dokonanie epoché, by go potem na drodze uniwersalnej autorefleksji na powrót odzyskać" 5 .

Fenomenologiczne rozjaśnienie tego, co istnieje, nie ma charakteru naukowego wyjaśnienia realnego faktu istnienia świata i wskazywania związków przyczynowych między realnie istniejącymi bytami, ponieważ wyklucza wszelkie naturalne czy naturalistyczne wyjaśnienia, polegając na uczynieniu zrozumiałym tego, co naturalnie niezrozumiałe, co należy do istoty poznania i poznawanego bytu, co nadaje im sens i podstawę ważności, niezależnie od faktyczno-empirycznych uwarunkowań. Krytyka poznania jest zatem niezależna od wszelkich wyjaśniających nauk realnych, sytuując się przed nimi, a zarazem ma sens „kry tyki poznania naturalnego we wszystkich naukach naturalnych" i umożliwia "poprawną i ostateczną interpretację wyników nauk naturalnych w odniesieniu do istniejącego bytu" ${ }^{6}$, jako że "teoriopoznawczy zamęt, do jakiego prowadzi naturalna (przedteoriopoznawcza) refleksja nad możliwością poznania (nad możliwą trafnością poznania), powoduje [...] nie tylko fałszywe poglądy na istotę poznania, lecz także z gruntu opaczne, gdyż w sobie sprzeczne, interpretacje bytu poznawanego w naukach naturalnych"7. Jeżeli chodzi o zagadkę istnienia świata, to krytyczne pytanie Husserla nie jest również - jak zauważa Elisabeth Ströker - pytaniem metafizycznym o to, skąd byt pochodzi, kto go wytworzył, lecz pytaniem fenomenologicznym o sens, w jakim możemy

Philosophie", red. Walter Biemel, w: Edmund Husserl, Gesammelte Werke, t. 6 (Den Haag: Martinus Nijhoff, 1962), 183-184. Cyt. za polskim przekładem fragmentów Kryzysu - Edmund Husserl, „Wybór pism”, przeł. Sławomira Walczewska, w: Krystyna Święcicka, Husserl (Warszawa: Wiedza Powszechna, 1993), 188.

4 Edmund Husserl, Idea fenomenologii. Pięć wykładów, przeł. Janusz Sidorek (Warszawa: PWN, 1990), 38.

${ }^{5}$ Edmund Husserl, Medytacje kartezjańskie, przeł. Andrzej Wajs (Warszawa: PWN, 1982), 236.

${ }^{6}$ Husserl, Idea fenomenologii, 33.

7 Tamże. 
mówić o bycie ${ }^{8}$, przy czym twórca fenomenologii dystansuje się jedynie od rozstrzygnięć klasycznej metafizyki jako filozofii pierwszej, ulegającej "spekulatywnej egzaltacji”, nie wykluczając metafizyki jako takiej'. Co więcej, Husserlowska krytyka poznania sytuuje się w obszarze Kantowskiej krytyki rozumu, bo jej celem jest - podobnie jak w krytycyzmie Kanta - nowe ugruntowanie metafizyki, która nie może już aspirować do filozofii pierwszej, ponieważ to właśnie fenomenologiczna teoria poznania staje się filozofią pierwszą i jako taka jest warunkiem koniecznie poprzedzającym i umożliwiającym metafizykę jako „naukę o tym, co istnieje w sensie absolutnym"10.

Akcentując analogię między Kantem i Husserlem w kwestii nowego ugruntowania metafizyki, Iso Kern doszukuje się „najgłębszego pokrewieństwa" między ich autorstwa krytykami rozumu, wskazując zarazem zasadniczą odmienność „duchowej sytuacji”, w jakiej filozofowie usiłowali dokonać takiego ugruntowania, co znajduje wyraz w „najgłębszej odmienności" wspomnianych krytyk ${ }^{11}$. Kant żył w epoce racjonalizmu, który absolutyzując czysto pojęciowe myślenie, skutkował aprioryczną metafizyką pogrążającą się $\mathrm{w}$ antynomiach i sprzecznościach, tak że nowe ugruntowanie metafizyki według myśliciela z Królewca polegało na wytyczeniu granic czystym pojęciom na podstawie ograniczenia ich ważności do przedmiotów możliwego doświadczenia, podczas gdy Husserl występuje przeciwko dominującemu w jego czasach fałszywemu zabsolutyzowaniu empiryczno-naukowego poznania i jego obiektywnego bytu przez wypływający z ducha pozytywizmu naturalizm, poddając krytyce obiektywne doświadczenie i naturalno-obiektywną wiedzę, krytyce wytyczającej granice naukom naturalnym, rozpoznającej ich właściwe miejsce i uwalniającej je od naturalistycznej naiwności, to znaczy wykazującej, że byt obiektywny nie jest bytem absolutnym ${ }^{12}$. To właśnie dzięki krytyce poznania - pisze Husserl w Idei fenomenologii - „wychodzi na jaw, że naturalne nauki o bycie nie są ostatecznymi naukami o bycie", w konsekwencji zaś krytyka nauk naturalnych toruje drogę właściwej metafizyce jako nauce o bycie absolutnym ${ }^{13}$.

Nauka ta, którą nazywamy metafizy ka, wyrasta z „krytyki” naturalnego poznania $\mathrm{w}$ poszczególnych naukach, krytyki przeprowadzonej

8 Zob. Elisabeth Ströker, „Intentionalität und Konstitution. Wandlungen des Intentionalitätskonzepts in der Philosophie Husserls", w: Elisabeth Ströker, Phänomenologische Studien (Frankfurt am Main: Vittorio Klostermann, 1987), 63.

9 Zob. Husserl, Medytacje kartezjańskie, 209.

${ }^{10}$ Husserl, Idea fenomenologii, 33.

11 Zob. Iso Kern, Husserl und Kant. Eine Untersuchung über Husserls Verhältnis zu Kant und zum Neukantianismus (Den Haag: Martinus Nijhoff, 1964), 187.

12 Zob. tamże, 187-188.

${ }_{13}$ Husserl, Idea fenomenologii, 33. Zob. Kern, Husserl und Kant, 188. 
na podstawie uzyskanego w ogólnej krytyce poznania wglądu w istotę poznania i przedmiotu poznania co do ich rozmaitych podstawowych postaci, wglądu w sens różnych fundamentalnych korelacji między poznaniem i przedmiotem poznania ${ }^{14}$.

\section{Istnienie nie jest realnym orzecznikiem}

Ludwig Landgrebe zaznacza, że fenomenologiczne rozjaśnienie sensu bytu okazuje się efektem odparcia naturalizmu, według którego „istniał tylko jeden sposób bycia, sposób »obiektywnie«, ściśle przyrodniczo dającego się określić przedmiotu i tylko jeden rodzaj praw, które określają zależności bytowe, przyczynowe prawodawstwo związku naturalnego"15. Naturalizm operuje zatem jednoznaczny m pojęciem bytu i praw między bytami, i ta jednoznaczność prowadzi do zaślepionego zabobonem faktu sceptycznego światopoglądu, generując niedorzeczności w formach circulus vitiosus czy regressus in infinitum i tym samym uniemożliwiając zrozumienie natury poznania i przedmiotu poznania. Husserl we wczesnej fazie swej myśli rozpoznaje niedorzeczność pewnej formy naturalizmu, jaką jest psychologizm, który zanegował obiektywną idealność przedmiotów logiki i praw logicznych, sprowadzając owe przedmioty do faktów psychicznych, a wspomniane prawa - do naturalnie określonych związków między faktami psychicznymi. Odrzucenie psychologizmu jest równoznaczne $\mathrm{z}$ zakwestionowaniem naturalizującej jednoznaczności bytu na rzecz jego zasadniczej wieloznaczności, jako że Husserl pokazuje w swej krytyce psychologizmu - aby odwołać się ponownie do komentarza Ludwiga Landgrebego - że "o bycie należy mówić w różny sposób", zgodnie z zasada, iż obiektywnie określony byt jako przedmiot nauk naturalnych nie jest jedynym bytem, gdyż istnieją przedmioty innego czy też wyższego porządku, jak np. przedmioty logiczne ${ }^{16}$.

W tym duchu poglądy Husserla komentuje również Emmanuel Lévinas, który mocno akcentuje zasadniczą wieloznaczność sensu bytu $\mathrm{w}$ fenomenologii ${ }^{17}$. Według Husserla bowiem struktura bytu nie jest tak sama: istnieją różne dziedziny bytu, np. przyroda, świat istot żywych, świadomość, które są przedmiotem odmiennych ontologii regionalnych (nazwanych ontologiami materialnymi) i nie można ich

${ }^{14}$ Husserl, Idea fenomenologii, 33.

${ }^{15}$ Ludwig Landgrebe, „Seinsregionen und regionale Ontologien in Husserls Phänomenologie", w: Ludwig Landgrebe, Der Weg der Phänomenologie. Das Problem einer ursprünglichen Erfahrung (Gütersloh: Gütersloher Verlagshaus Gerd Mohn, 1963), 143.

16 Tamże.

17 Zob. Emmanuel Lévinas, Théorie de l'intuition dans la phénoménologie de Husserl (Paris: Librairie Philosophique J. Vrin, 1994), 21-22. 
opisywać za pomocą tych samych kategorii. Ontologie materialne odpowiadają zatem poszczególnym dziedzinom bytu (Seinsregionen), a pojęcie dziedziny jest określone jako „do pewnego konkretu przynależna najwyższa jedność rodzajów"18 (kategorii czy istot materialnych). Do opisu różnych dziedzin bytowych można wprawdzie stosować uniwersalne pojęcia formalno-ontologiczne, jak: przedmiot, relacja, własność, ponieważ ontologia formalna jest teorią przedmiotu w ogóle, abstrahującą od jego wszelkich materialnych określeń, ale w fenomenologii relacja tego, co formalne, do tego, co materialne, nie jest relacją rodzaju do gatunku. Forma bowiem nie jest najwyższym rodzajem, którego gatunkami byłyby momenty materialne, dlatego prawdy orzekające o materialnej strukturze bytu nie są uszczegółowieniami prawd formalno-ontologicznych ${ }^{19}$. W ten sposób ontologia formalna - odwołajmy się do Husserla - „przepisuje [...] z gór y ontologiom materialnym pewną wspólną im wszystkim formalną strukturę"20, ale ontologie materialne zachowują niezależność od ontologii formalnej, tak że Husserl mocno akcentuje wielość różnych, niesprowadzalnych do siebie obszarów bytowych, które są przedmiotem odmiennych ontologii regionalnych.

Poszczególne dziedziny bytu - jak trafnie zauważa Lévinas - różnią się zarówno co do istot i kategorii, które je opisują jak i co do swego istnienia, ponieważ istnienie nie jest uniwersalną i pustą charakterystyką dołączającą się do istot, dlatego nie tylko istoty określają specyfikę dziedzin bytowych, lecz także istnienie ${ }^{21}$. Tak więc przedmiotem fenomenologii jest zarówno istota bytu, jak i jego istnienie, a „istnieć nie znaczy wszędzie tego samego" 22 . W tym kontekście Husserl dokonuje rozróżnienia między Sein i Sosein: o ile w tym rozróżnieniu Sein oznacza istnienie (Existenz), o tyle Sosein - poddawane analizie istotnościowej bycie czymś, tak że rozróżnienie między Sein i Sosein koresponduje z tradycyjnym rozróżnieniem między existentia i essentia ${ }^{23}$. Husserl używa zatem słowa Sein w znaczeniu istnienia w przeciwstawieniu do Sosein, poza

18 Edmund Husserl, Idee czystej fenomenologii i fenomenologicznej filozofii. Księga pierwsza, przeł. Danuta Gierulanka (Warszawa: PWN, 1975), 53.

19 Zob. tamże, 43-55.

20 Tamże, s. 39.

${ }_{21}$ Zob. Lévinas, Théorie de l'intuition dans la phénoménologie de Husserl, 21-22.

22 Tamże, 22.

${ }^{23}$ Na temat rozróżnienia Sein i Sosein zob. Edmund Husserl, „Ding und Raum. Vorlesungen 1907", red. Ulrich Claesges, w: Edmund Husserl, Gesammelte Werke, t. 16 (Den Haag: Martinus Nijhoff, 1973), 288-290; Edmund Husserl, „Erste Philosophie (1923/24)”, cz. 2: „Theorie der phänomenologischen Reduktion”, red. Rudolf Boehm, w: Edmund Husserl, Gesammelte Werke, t. 8 (Den Haag: Martinus Nijhoff, 1959), 396-397; Husserl, Medytacje kartezjańskie, 86, 93; Edmund Husserl, „Zur Phänomenologie der Intersubjektivität. Texte aus dem Nachlass", cz. 2: 1921-1928, red. Iso Kern, w: Edmund Husserl, Gesammelte Werke, t. 14 (Den Haag: Martinus Nijhoff, 1973), 151-160. 
tym przeciwstawieniem zaś $\mathrm{w}$ fenomenologii słowo Sein nabiera innego sensu. Zauważmy, że egzystencjalne znaczenie słowa Sein (w sensie istnienia) jest jego znaczeniem węższym, a twórca fenomenologii posługuje się tym słowem również w znaczeniu szerszym, tj. znaczeniu obejmującym i przekraczającym pojęcie istnienia. Jeżeli chodzi o Sein w szerszym znaczeniu, to odnosi się ono nie tylko do egzystencjalnego, lecz także orzeczeniowego czy przydawkowego użycia tego słowa, i można je przełożyć na język polski - żeby się odwołać do wykładni tłumacza tekstów Husserla Janusza Sidorka - jako bycie ${ }^{24}$.

W Badaniach logicznych Husserl, precyzując szersze znaczenie Sein, pisze:

Tutaj przypominamy sobie twierdzenie Kanta: Bycie (Se in) nie jest realnym orzecznikiem (reales Prädikat). Jeśli nawet odnosi się ono do bycia egzystencjalnego, bycia ",absolutnego ustalania (Position)", jak to też nazwał Herbart, to przecież w nie mniejszym stopniu możemy posłużyć się nim w odniesieniu do bycia orzeczeniowego i przydawkowego. W każdym razie chodzi w nim o dokładnie to, co tutaj chcemy rozjaśnić. Mogę widzieć barwę, ale nie b y c i e barwnym. Mogę wyczuwać gładkość, ale nie b y c i e gładkim. Mogę słyszeć dźwięk, ale nie b y c i e dźwięcznym. Bycie nie jest czymś $w$ przedmiocie, nie jest jego częścia, zawartym w nim momentem, jakością albo intensywnością, ale także nie jest figura, w ogóle wewnętrzną forma, nie jest, jakkolwiek by ją ujmować, cechą konstytutywną. Bycie jednakże również nie jest czymś na przedmiocie, tak jak nie jest realną cechą wewnętrzna, tak też nie jest realną cechą zewnętrzna, i dlatego w r e al n y m sensie w ogóle nie jest „cechą" 25 .

Formułując tezę Sein ist kein reales Prädikat, Husserl nawiązuje bezpośrednio do Kanta, który już w tekście przedkrytycznym, pt. Jedyna możliwa podstawa dowodu na istnienie Boga, pisze, że „istnienie nie jest predykatem ani określeniem jakiejś rzeczy" ${ }^{26}$. Z kolei w Krytyce czystego rozumu czytamy: „»Istnienie« nie jest oczywiście realnym orzeczeniem, tzn. pojęciem czegoś, co może dołączać się do pojęcia pewnej rzeczy. Jest ono jedynie uznaniem $\mathrm{w}$ istnieniu (Position) pewnej rzeczy lub pewnych własności samych w sobie"27.

24 Zob. Husserl, Badania logiczne, t. 2, cz. 2, 163.

${ }_{25}$ Tamże, 163-164.

26 Immanuel Kant, ,Jedyna możliwa podstawa dowodu na istnienie Boga”, przeł. Translatorium Filozofii Niemieckiej Instytutu Filozofii UMK pod kierunkiem Mirosława Żelaznego, w: Immanuel Kant, Dzieła zebrane, t. 1: Pisma przedkrytyczne, red. Marek Jankowski, Tomasz Kupś (Toruń: Wydawnictwo Naukowe UMK, 2010), 534.

${ }^{27}$ Immanuel Kant, Krytyka czystego rozumu, przeł. Roman Ingarden (Kęty: Wydawnictwo ANTYK, 2001), A 598/B 626. 
Jeżeli chodzi o Kanta, to mówiąc, że istnienie nie jest ani predykatem, ani określeniem rzeczy, ma on na uwadze to, że „istnienie jest absolutną pozycją rzeczy i poprzez to odróżnia się od każdego predykatu, który jako taki zawsze jest jedynie względnie ustanowiony wobec innej rzeczy $^{28}$. W ten sposób absolutne ustanowienie czy uznanie $w$ istnieniu czegoś ze względu na nie samo, typu $a$ istnieje, zostaje odróżnione od ustanowienia względnego, wyrażającego relację predykatu do podmiotu, typu $a$ jest $b$. W pierwszym wypadku słowo Sein oznacza Dasein, a w drugim jest ono użyte logicznie jako copula w sądzie ${ }^{29}$. Dlatego bycia czymś, stanowienia względnego, a ściślej: stanowienia realności (rzeczowej zawartości przedmiotu) nie należy mieszać z byciem w sensie istnienia, stanowieniem absolutnym. Według Kanta istnienie nie jest realnym orzeczeniem, ponieważ pojęcia realności i istnienia to zupełnie odmienne kategorie. Kategoria realności wraz z kategoriami przeczenia i ograniczenia należy do kategorii jakości i jest równoznaczna z pojęciem rzeczowości (Sachheit) czy transcendentalnego stwierdzenia (Bejahung) ${ }^{30}$. Z kolei kategoria istnienia wespół z kategoriami możliwości i konieczności należy do grupy kategorii modalności, a kategorie modalności nie są żadnymi treściowymi określeniami przedmiotu, lecz jedynie wyrażają jego stosunek do naszych władz poznawczych. „Kategorie modalności odznaczają się tym, że jako określenie przedmiotu wcale nie wzbogacają pojęcia, do którego są dołączone jako orzeczenie, lecz wyrażają tylko stosunek [przedmiotu] do zdolności poznawczej" ${ }^{31}$. W przeciwieństwie do możliwości, która jest ,jedynie ujęciem rzeczy w jej stosunku do intelektu", „,rzeczywistość jest zarazem jej powiązaniem ze spostrzeżeniem”32, dodajmy: ze spostrzeżeniem jako świadomością uznającą w istnieniu. Skoro zatem istnienie nie jest realnym orzeczeniem, „to, co rzeczywiste, nie zawiera nic więcej niż to, co jedynie możliwe" ${ }^{\prime 3}$, a istnienie przedmiotu okazuje się absolutnym stanowieniem na podstawie spostrzeżenia, które „jest jedynym charakterem rzeczywistości” ${ }^{34}$, w konsekwencji zaś „dokąd [...] sięga spostrzeżenie [...], tam też sięga nasze poznanie istnienia rzeczy" ${ }^{\prime 35}$.

Husserl, formułując tezę Sein ist kein reales Prädikat, nawiązuje wprawdzie do Kanta, ale nie można nie zauważyć zasadniczej różnicy między tymi filozofami w kwestii rozumienia owej tezy. W formule Sein ist kein reales Prädikat Husserl bowiem rozszerza znaczenie słowa Sein

28 Kant, ,Jedyna możliwa podstawa dowodu na istnienie Boga”, 535.

29 Zob. tamże, 535-537; Kant, Krytyka czystego rozumu, A 598/B 626.

30 Zob. Kant, Krytyka czystego rozumu, A 574-575/B 602-603.

31 Tamże, A 219/B 266

32 Tamże, B 288.

33 Tamże, A 599/B 627.

34 Tamże, A 225/B 273.

35 Tamże, A 226/B 273. 
tak, że obejmuje ono również jego użycie orzeczeniowe, natomiast Kant $\mathrm{w}$ tej formule Sein rozumie jedynie w sensie egzystencjalnym, jako że intencją filozofa z Królewca jest przeciwstawienie bycia egzystencjalnego, $\mathrm{w}$ sensie absolutnego ustanowienia, byciu $\mathrm{w}$ znaczeniu ustanowienia względnego, wyrażającemu relację predykatu do podmiotu. Rozszerzenie znaczenia słowa Sein przez Husserla w tej tezie jest motywowane potrzebą unaocznienia sensu bycia i idzie w parze - zupełnie inaczej niż u Kanta - z rozszerzeniem naoczności poza sferę zmysłową ${ }^{36}$. Husserl jednak - jak już zasygnalizowaliśmy - używał również słowa Sein w wąskim egzystencjalnym sensie (Existenz), przeciwstawionym Sosein (byciu czymś). Jeżeli zawęzimy sens słowa Sein do jego funkcji egzystencjalnej, to $\mathrm{w}$ fenomenologii tezę Sein ist kein reales Prädikat można przełożyć jako „istnienie nie jest realnym orzecznikiem”, i w takim wypadku analogia między Husserlem i Kantem odnośnie do rozumienia istnienia jest bardziej rozpoznawalna niż różnica między nimi w tej kwestii. Mając na uwadze interesującą nas problematykę istnienia w fenomenologii Husserla, w dalszej części tekstu zaprezentujemy egzystencjalną wykładnię analizowanej tezy, wykładnię nawiązującą nie tylko terminologicznie, lecz także rzeczowo do Kanta.

Kantowskie rozumienie istnienia jako absolutnego ustanowienia, które nie stanowi realnej własności przedmiotu i zostaje powiązane z władzą poznawczą a ściślej - ze spostrzeżeniem, pozostaje w zasadniczej analogii do Husserlowskiej idei korelacji zachodzącej między bytem i świadomością, zgodnie z którą źródłem wykazywania sensu istnienia rzeczy jest doświadczenie, ponieważ „c z y m k olwiek są rzeczy [...], tym sąone jako rzeczy doświadczenia”, które „przepisuje im ich s e n s"37. Rzecz jasna Husserl, w przeciwieństwie do Kanta, kwestionuje możliwość niepoznawalnych, pozadoświadczalnych rzeczy samych w sobie jako nieempirycznego fundamentu zjawisk, ale w interesującej nas kwestii wykazywania istnienia rzeczy różnica między Kantem i Husserlem traci na ostrości. Iso Kern zwraca uwagę na to, że w filozofii Kanta rzecz sama w sobie nie musi być rozumiana jako zewnętrzny wobec wszelkiej świadomości przedmiot, ponieważ Kant nadaje pojęciu tej rzeczy również pozytywne znaczenie, akcentując jej związek z naocznością inną niż nasza, naocznością niezmysłowa, dla nas niepojmowalną, jaką dysponowałby tylko intelekt boski (intellectus archetypus), naocznością z której taka rzecz musiałaby ostatecznie czerpać swój sens ${ }^{38}$. W tym kontekście w Krytyce czystego rozumu czytamy:

36 Zob. Husserl, Badania logiczne, t. 2, cz. 2, 163-172.

37 Husserl, Idee czystej fenomenologii i fenomenologicznej filozofii, 141-142.

38 Zob. Kern, Husserl und Kant, 124-125. 
Ażeby [...] słowo noumenon oznaczało prawdziwy przedmiot, dający się odróżnić od wszelkich fenomenów, na to nie wystarcza, bym myśl mą wyzwolił z wszelkich warunków zmysłowej naoczności; muszę ponadto posiadać podstawę do tego, żeby przyjąć inny niż naoczność zmysłowa rodzaj naoczności, w której taki przedmiot mógłby być dany; inaczej bowiem myśl moja jest pusta, choć wolna od sprzeczności ${ }^{39}$.

Husserl, w odróżnieniu od Kanta, rozszerza wprawdzie pojęcie naoczności poza sferę zmysłowa, kwestionując zarazem ideę intellectus archetypus, ale zgadza się z Kantem w kwestii wykazywania sensu istnienia rzeczy w naoczności: mówienie o jakichkolwiek istniejących rzeczach byłoby całkowicie puste, gdybyśmy nie wskazali aktów naocznych, w których są one dane.

W związku z teza, że istnienie nie jest predykatem ani określeniem rzeczy, lecz na mocy absolutnej pozycji zostaje przypisane domniemanej przez pojęcie rzeczy (wraz z wszystkimi jej własnościami) na podstawie spostrzeżenia zmysłowego, Kant pisał, iż „sto rzeczywistych talarów nie zawiera nic więcej niż sto możliwych" ${ }^{40}$, bo pojęcie tego, co rzeczywiste, zawiera dokładnie to samo, co pojęcie tego, co możliwe. W podobnym duchu wypowiada się Husserl na temat rozróżnienia przedmiotu tylko intencjonalnego i rzeczywistego już w swej wczesnej rozprawie, pt. Intencjonalne przedmioty (1894): „Tylko intencjonalny przedmiot jest przedmiotem nieistniejącym, prawdziwy przedmiot - istniejącym: pojęcia mają zapewne ten sam zakres. Wyłączenie istnienia jest w pierwszym przypadku wyrażone w słówku »tylko «"41. Skoro istnienie nie jest realnym orzecznikiem, „błędem jest - jak pisze Husserl w późniejszym dziele: Badaniach logicznych (1900/1901) - gdy ktoś w ogóle wprowadza realną (reellen) różnicę między przedmiotem »tylko immanentnym «albo »intencjonalnym $\ll \mathrm{z}$ jednej strony a ewentualnie odpowiadającym $\mathrm{mu}$ przedmiotem »rzeczywistym $« \mathrm{i} »$ transcendentnym $« \mathrm{z}$ drugiej $[\ldots]^{\prime \prime 4}$. Konkluzja autora Badań logicznych jest następująca:

Wystarczy to tylko wypowiedzieć, aby każdy musiał uznać: ż e in te ncjonalny przedmiot przedstawienia jest ten sam co jego przedmiot rzeczywisty i w danym wypadku zewnętrzny, i że niedorzeczne jest odróżnianie i ch od siebie. Przedmiot transcendentny wcale nie byłby p r z ed-

39 Kant, Krytyka czystego rozumu, A 252.

40 Tamże, A 599/B 627.

${ }^{41}$ Edmund Husserl, „Aufsätze und Rezensionen (1890-1910)", red. Bernhard Rang, w: Edmund Husserl, Gesammelte Werke, t. 22 (The Hague-Boston-London: Martinus Nijhoff, 1979), 315.

${ }^{42}$ Husserl, Badania logiczne, t. 2, cz. 1, 532. 
miotem tego przedstawienia, gdyby nie był jego przedmiotem intencjonaln $\mathrm{y} \mathrm{m}^{43}$.

W fenomenologii różnica między przedmiotem tylko intencjonalnym a przedmiotem rzeczywistym musi być jednak zachowana, ale różnica ta - odwołajmy się do Bernharda Ranga - „nie jest różnicą »realną", lecz różnicą dotyczącą »sposobu dania «" 44 . Husserl wychodzi od koncepcji poznania jako procesu wypełniania naocznością początkowo pustych, sygnitywnych intencji domniemujących przedmiot, przy czym naoczność spostrzeżeniowa jest archetypiczną formą wszelkiej naoczności, a przedmiot rzeczywiście istniejący jest przedmiotem o wyróżnionym sposobie dania, jakim okazuje się danie spostrzeżeniowe, toteż samoprezentacja przedmiotu w oczywistości spostrzeżeniowej jest „uchwyceniem bytu oraz jego określeń w modus "własnej osoby «"45. Stąd wniosek, że "rzeczywiście nie znaczy [...] tyle co poza świadomościa, lecz tylko tyle co nie jedynie domniemane" ${ }^{\prime 4}$. W konsekwencji przedmiot rzeczywiście istniejący nie jest przedmiotem zewnętrznym, istniejącym obiektywnie, niezależnie od świadomości, a rozróżnienie przedmiotu tylko intencjonalnego i przedmiotu rzeczywistego jest zorientowane na stosunek wypełnienia percepcyjną treścią intencji domniemującej przedmiot: przedmiot rzeczywisty jest nie tylko przedmiotem domniemanym (danym sygnitywnie, pusto), lecz także przedmiotem danym naocznie, i to danym "we własnej osobie", spostrzeżeniowo, w modus samoprezentacji (Selbstgebung), w odróżnieniu od dania naocznego właściwego uobecnieniom (Vergegenwärtigung), dania imaginacyjnego (charakteryzującego przedmioty fikcyjne) czy też dania przypomnieniowego ${ }^{47}$. Gdy przedmiot jest "tylko intencjonalny", istnieje nie sam przedmiot, lecz intencja, domniemywanie ${ }^{48}$, przy czym skoro istnienie nie jest re-

43 Tamże, 533.

44 Bernhard Rang, Kausalität und Motivation. Untersuchungen zum Verhältnis von Perspektivität und Objektivität in der Phänomenologie Edmund Husserls (Den Haag: Martinus Nijhoff, 1973), 23.

${ }^{45}$ Husserl, Medytacje kartezjańskie, 22. Zauważmy, że sam przedmiot rzeczywiście istniejący jest nie tylko przedmiotem domniemanym, lecz także danym, i to danym dokładnie w taki sposób, w jaki wcześniej był domniemany, w konsekwencji zaś w procesie wypełniania intencji naocznością jeden i ten sam przedmiot jest ujęty w „,jak" swego dania. Zob. Rang, Kausalität und Motivation, 23.

${ }^{46}$ Husserl, Badania logiczne, t. 2, cz. 2, 295. Zob. Dan Zahavi, Intentionalität und Konstitution. Eine Einführung in Husserls "Logische Untersuchungen“ (University of Copenhagen: Museum Tusculanum Press, 1992), 108-111.

${ }^{47}$ Można zatem doszukać się zasadniczej analogii między Kantem i Husserlem w kwestii związku między spostrzeżeniem i rzeczywistościa, przy czym Husserl, w odróżnieniu od Kanta, pojęcie spostrzeżenia rozumie w szerokim sensie, obejmującym również spostrzeżenia kategorialne, niezmysłowe.

${ }^{48}$ Zob. Husserl, Badania logiczne, t. 2, cz. 1, 533. 
alnym orzecznikiem, lecz pozostaje $\mathrm{w}$ nierozerwalnym związku z wypełnieniem intencji naocznością spostrzeżeniowa, to właśnie wyłączenie naoczności ma rozstrzygające znaczenie dla pojęcia samej tylko intencji i tylko intencjonalnego przedmiotu ${ }^{49}$. Jeżeli zaś przedmiot intencjonalny istnieje, to istnieje nie tylko domniemywanie, lecz także to, co domniemane, i to $\mathrm{w}$ tym znaczeniu, że to, co domniemane, dochodzi do spostrzeżeniowej samoprezentacji. W konsekwencji istnieje wówczas przedmiot sam w sobie „w jedynym wchodzącym tu w grę i zrozumiałym sensie, który realizowany byłby przez wypełnienie intencji spostrzeżeniowej" ${ }^{\prime \prime 0}$.

\section{Istnienie świata a istnienie świadomości}

Teza „istnienie nie jest realnym orzecznikiem” oznacza nie tylko, że różnica między przedmiotem nieistniejącym, tylko intencjonalnym a przedmiotem istniejącym jest różnicą $\mathrm{międ} \mathrm{zy} \mathrm{sposobami} \mathrm{dania} \mathrm{(sygnityw-}$ ny, uobecniony, spostrzeżeniowy), lecz także, że pojęcie istnienia nie jest pustą kategoria, która ma zastosowanie do wszelkich istniejących przedmiotów, ale różnicuje się w ob rę b i e sposobów naocznego, a ściślej: spostrzeżeniowego dania tego, co jest, dlatego też różnice między rzeczywiście istniejącymi przedmiotami są również różnicami dotyczącymi sposobu ich dania. Według Husserla zasadnicza różnica co do sposobów rzeczywistego (faktycznego) istnienia zachodzi między bytem immanentnym, absolutnym (świadomością) i bytem transcendentnym, względnym (światem czy realnością), i ta różnica między immanencją i transcendencją jest ugruntowana w „za sa dniczej różnicy w sposobie dania"51.

Zaryzykujmy twierdzenie, że teza „istnienie nie jest realnym orzecznikiem" doprowadziła Husserla do koncepcji redukcji fenomenologicznej. Redukcja fenomenologiczna bowiem stawia sobie za cel odsłonięcie zakrytej w nastawieniu naturalnym korelacji noetyczno-noematycznej i może być rozumiana jako zmiana nastawienia z nastawienia naturalnego na fenomenologiczne; zmiana, polegająca na tym, że to, co rzeczywiście istniejące, zostaje potraktowane jako noemat, to znaczy korelat mnogości noetycznych aktów świadomościowych, korelat wzięty dokładnie tak, jak jest dany, przy wyłączeniu (epoché) obiektywnego istnienia (istnienia „W sobie” ${ }^{\prime \prime}$. W ten sposób - komentuje Marek J. Siemek - Husserl wpisuje się w tradycję kantowsko-fichteańską poszukując podstawy

49 Zob. Bernhard Rang, „Einleitung des Herausgebers”, w: Edmund Husserl, Aufsätze und Rezensionen (1890-1910), L-LI.

50 Husserl, Badania logiczne, t. 2, cz. 2, 71.

${ }^{51}$ Husserl, Idee czystej fenomenologii i fenomenologicznej filozofii, 124, 149-150. 
i źródła ważności tego, co rzeczywiście istniejące „nie w jakimś obiektywno-metafizycznym uposażeniu samych »rzeczy« (Kant i Fichte powiedzieliby: rzeczy samych w sobie - Dinge-an-Sich), lecz w pierwotnie syntetycznych aktach podmiotowego ustanawiania (Setzung) i nadawania sensu (Sinngebung), dzięki którym sam byt przedmiotów wyłania się dopiero w konstytuującym go horyzoncie swoistych sensów przedmiotowych (Gegenstandssin $n)^{\prime \prime 52}$. Uściślając, według samego Husserla, w odniesieniu do rzeczy podmiotowym ustanowieniem, to znaczy świadomością ustalająca, tetyczną (positionales Bewusstsein), jest spostrzeżenie zewnętrzne, transcendentne, ponieważ - jak wcześniej zasygnalizowaliśmy - przypisanie przedmiotowi rzeczywistego istnienia następuje na podstawie spostrzeżenia. To właśnie spostrzeżenie ma charakter samoprezentacji przedmiotu, zawierającej moment uznania przedmiotu za coś istniejącego rzeczywiście, a odpowiednikiem owego uznania (po stronie noematycznej) jest przysługujący temu przedmiotowi charakter bycia rzeczywistym ${ }^{53}$. Jeżeli zaś chodzi o świat jako horyzont, zawsze już potencjalnie obecny $\mathrm{w}$ aktualnym doświadczeniu jednostkowych rzeczy, urzeczywistniający możliwość jednozgodności przebiegu całego doświadczenia, to jego istnienie jest odpowiednikiem generalnej tezy nastawienia naturalnego jako uniwersalnej przeświadczeniowej pewności (Glaubensgewißßheit), prapostaci wszelkiego uznawania istnienia, uświadamianej w przebiegu możliwych i rzeczywistych spostrzeżeń ${ }^{54}$. Ta uniwersalna, przeświadczeniowa pewność istnienia świata oznacza $\mathrm{w}$ istocie „bierna wiarę bytowa, która nie ma jeszcze w sobie nic z dokonania poznawczego", należąc do obszaru pierwotnej pasywności, poprzedzającej wszelką podmiotową aktywność, a więc również aktywność wydawania sądów ${ }^{55}$.

Husserl mocno akcentuje, że uznanie istnienia jednostkowych, zewnętrznych wobec świadomości przedmiotów jest przypadkowe i może być przekreślone $\mathrm{w}$ dalszym przebiegu doświadczenia, a przekreślenie to skutkuje pozbawieniem charakteru istnienia tego, co uprzednio było domniemane jako realnie istniejące. Uznanie istnienia konkretnych rzeczy dokonuje się bowiem w spostrzeżeniu transcendentnym, które jest $\mathrm{z}$ istoty nieadekwatnym i powątpiewalnym spostrzeżeniem, ponieważ rzeczy nigdy nie są dane wszechstronnie, lecz wielostronnie, jawią się

${ }^{52}$ Marek J. Siemek, „Husserl i dziedzictwo filozofii transcendentalnej”, w: Filozofia transcendentalna a dialektyka, red. Marek J. Siemek (Warszawa: Oficyna Naukowa, 1994), 279.

53 Zob. Husserl, Idee czystej fenomenologii i fenomenologicznej filozofii, 336-342.

54 Zob. tamże, 86-87, 338-341. „Świadomość świata - czytamy w Doświadczeniu i sądzie - jest świadomością w modus pewności wiary [...]". Edmund Husserl, Doświadczenie $i$ sąd. Badania nad genealogia logiki, przeł. Bogdan Baran (Warszawa: Fundacja Aletheia, 2013), 40.

55 Tamże, 66. 
w różnych wyglądach, przejawach, horyzontach, wskazując nieskończone kontinuum ujęć naocznych. W konsekwencji każdy skończony ciąg spostrzeżeń, w którym są nam aktualnie dane rzeczy, pozostawia w zawieszeniu dalszy przebieg doświadczenia, otwierając zarazem możliwość zmiany tego przebiegu lub unieważnienia go w nowym ciągu spostrzeżeń. Również generalna teza nastawienia naturalnego jako uniwersalna apercepcja świata $\mathrm{w}$ modus przeświadczeniowej pewności, przenikająca wszelką świadomość ustalającą (tetyczną), jest przypadkowa. Zawarte $\mathrm{w}$ spostrzeżeniach zewnętrznych pojedyncze tezy egzystencjalne dotyczące konkretnych rzeczy mogą wprawdzie zostać przekreślone w przebiegu doświadczenia, nie naruszając w niczym obowiązywania przeświadczeniowej pewności dotyczącej świata, pewności prawomocnej, bo stale się potwierdzającej w przebiegu doświadczenia, ale nie zmienia to faktu, że pewność ta ma charakter pewności presumpcyjnej, nie zaś apodyktycznie pewnej (czyli takiej, która wykluczałaby możliwość pomyślenia nieistnienia tego, co w niej dane). Według Husserla bowiem to, że świat istnieje, stanowi odpowiednik zawartego w przeświadczeniowej pewności uznania jego istnienia, a uznanie to dokonuje się na mocy domniemującej antycypacji, że przyszły faktyczny ciąg doświadczeń będzie stale potwierdzał jego dotychczasowy jednozgodny przebieg, antycypacji pozbawionej waloru pewności apodyktycznej, jako że nie sposób wykluczyć możliwości załamania się nie tylko pojedynczych doświadczeń, lecz także jednozgodności całego doświadczenia apercypującego rzeczywistość w modus pewności istnienia, to znaczy możliwości rozpłynięcia się wszelkich doświadczeń w natłoku wrażeń, możliwości unicestwienia świata ${ }^{56}$.

O ile istnienie rzeczy i świata jest istnieniem względnym, danym w nieadekwatnym, presumpcyjnym doświadczeniu, to tyle moja świadomość stanowi niepowątpiewalną dziedzinę bytową bo jest "źródłowo i absolutnie dana, nie tylko w [swej] istocie (Essenz), lecz w [swym] istnieniu (Existenz) "57; jako taka, jest „sferą absolutnego ustalania (Position)" ${ }^{\prime 2}$. W Ideach I Husserl pisze wprost: „Te zi e [dotyczącej] ś wi a ta, która jest "przypadkowa", przeciwstawia się teza [dotycząca] mojego czystego Ja i życia podmiotowego (Ichleben), k tóra jest »k o n i e c z n a ", w ogóle niepowątpiewalna" 59 . Zauważmy, że świadomość nie jest czymś jedynie domniemanym, nie jest pustym logicznym Ja czy też wykoncypowanym za pomocą analizy uniesprzeczniającej formalnym warunkiem możliwości, lecz jest świadomością aktualnie doświadczająca, faktycznie istniejąca, a słowo

\footnotetext{
${ }_{56}$ Zob. Husserl, Idee czystej fenomenologii i fenomenologicznej filozofii, 146-147.

57 Tamże, 137.

58 Tamże, 138.

59 Tamże, 139.
} 
„istnienie" w odniesieniu do świadomości ma zupełnie inny sens niż uznawane $\mathrm{w}$ tezie nastawienia naturalnego „istnienie" bytu transcendentnego. Wszystko bowiem, co istnieje poza świadomością, wymaga odniesienia do doświadczającej świadomości, w której jest dane. Dlatego dziedzina świadomości to „pewna zasadniczo swoista dziedzina bytowa" ${ }^{60}$, a ściśle mówiąc, dziedzina świadomości nie jest jedną z wielu dziedzin, lecz stanowi „prakategorię bytu w ogóle (albo w naszym języku: pra-dziedzinę), w której tkwią korzeniami wszystkie inne dziedziny bytu, do której ze swej is to ty nawiązuja, od której zatem są wszystkie zależne" ${ }^{\prime \prime 1}$. Wszelki byt spoza mojej świadomości okazuje się czymś zasadniczo ukonstytuowanym i odsyła do konstytuującej świadomości, która ma charakter świadomości czystej, transcendentalnej, podniesionej do rangi bytu absolutnego ${ }^{62}$. Husserl tak to ujmuje:

Poprzez transcendentalną epoché dostrzegam [...], że wszystko, co istnieje w świecie - dotyczy to również istnienia mojego jako człowieka - jest dla mnie czymś istniejącym (Daseiendes), jedynie jako treść pewnej apercepcji doświadczającej w modus pewności istnienia. Jako transcendentalne Ego jestem dokonującym tej apercepcji, przeżywającym ją Ja. Jest ona dzianiem się we mnie, skrywającym się co prawda przed refleksja, dzianiem się, w którym przede wszystkim konstytuują się dla mnie jako istniejące świat i ludzka osoba ${ }^{63}$.

W odróżnieniu od rzeczy danych w spostrzeżeniu transcendentnym czysta świadomość jest dana w sposób niepowątpiewalny w refleksji, którą stanowi spostrzeżenie immanentne, mające charakter apodyktycznej i zasadniczo adekwatnej samoprezentacji tego, co dane. W wypadku spostrzeżenia immanentnego nie zachodzi zdwojenie na przejaw i to, co dane przez przejaw, ponieważ jego przedmiotem jest przeżycie, które należy do tego samego strumienia świadomości, co samo to spostrzeżenie, wobec czego „spostrzeżenie i to, co spostrzeżone, tworzą zistoty niezapośredniczoną jedność, jedność jednej jedynej konkretnej cogitati $0^{\prime \prime 64}$. W wypadku przeżyć poznanie (spostrzeżenie immanentne) obejmuje zatem to, co poznane, tak że przedmiot zostaje doskonale uchwycony jako to, czym jest i że jest, tzn. jest w poznaniu efektywnie samoobecny w całej swej zawartości. Tak więc, w odniesieniu do sfery przeżyć - konkluduje Husserl - „nie

60 Tamże, 97.

61 Tamże, 223.

${ }^{62}$ Zob. Landgrebe, „Seinsregionen und regionale Ontologien in Husserls Phänomenologie", 147-148.

${ }^{63}$ Edmund Husserl, „Fenomenologia i antropologia”, przeł. Sławomira Walczewska, Archiwum Historii Filozofii i Myśli Społecznej 32 (1987): 342.

${ }^{64}$ Husserl, Idee czystej fenomenologii i fenomenologicznej filozofii, 111. 
ma różnicy między zjawiskiem i bytem (Sein), a o ile natura jest czymś istniejącym (Dasein), co przejawia się w zjawiskach, to same zjawiska [...] nie są znowu bytem, przejawiającym się przez kolejne zjawiska" ${ }^{65}$. Jeżeli moje życie podmiotowe, w odróżnieniu od rzeczy, nie prezentuje się perspektywicznie przez przejawy, to nie wymaga potwierdzania w dalszym przebiegu doświadczenia i nie może zostać pozbawione charakteru istnienia, toteż refleksja $\mathrm{w}$ sensie spostrzeżenia immanentnego „posiada z istoty płynący charakter oczywiście niepodważalnej tezy o istnieniu (Daseinsthesis)" ${ }^{\prime \prime 6}$.

Świadomość jest wprawdzie dana niepowątpiewalnie co do istnienia w refleksji jako świadomości uprzedmiotowiającej (spostrzeżeniu immanentnym), w której przeżycia są uznawane w bycie jako przedmioty, ale świadomość istnieje koniecznie nie dlatego, że jest przedmiotem osadzającej w bycie refleksji, ponieważ jest absolutną rzeczywistością, a zatem istnieje bezwarunkowo, bez względu na to, czy jest poddawana refleksji, czy też nie, i to właśnie istnienie świadomości jest źródłem i warunkiem wszelkiej refleksji, stanowiącej jej w tó rną s a m o ob i ek ty w i z a cję, w ramach której konstytuuje się ona jako strumień przeżyć, ujmowanych aktowo jako przedmioty istniejące ${ }^{67}$. Gdyby istnienie było przypisywane świadomości w aktach refleksji, to wymagałaby ona dalszej prezentującej świadomości, która również nie miałaby charakteru absolutnej świadomości, ponieważ ze swej strony mogłaby być dana tylko w aktach świadomości reflektującej wyższego stopnia, i tak w nieskończoność. W konsekwencji w ramach refleksyjnego modelu świadomości, który prowadzi do nieskończonego regresu, pojęcie absolutnej świadomości jest pozbawione sensu. Stąd wniosek, że jeżeli mówimy o absolutnej świadomości, to mamy na uwadze istnienie świadomości w jej niezależności od aktów refleksji. Emmanuel Lévinas w ten sposób komentuje absolutny charakter świadomości. „Na tym istnieniu dla siebie świadomości - uprzednim względem refleksji, która

65 Edmund Husserl, Filozofia jako ścisła nauka, przeł. Włodzimierz Galewicz (Warszawa: Fundacja Aletheia, 1992), 39.

${ }_{66}$ Husserl, Idee czystej fenomenologii i fenomenologicznej filozofii, 139.

67 Zob. tamże, 362; Lévinas, Théorie de l'intuition dans la phénoménologie de Husserl, 54-57. W tym kontekście w Ideach I czytamy, że to, co w refleksji „spostrzeżeniowo uchwycone, charakteryzuje się zasadniczo jako coś, co nie jest i trwa w zasięgu spostrzegającego spojrzenia, lecz j u ż b y ło, z a n i m się owo spojrzenie ku niemu zwróciło. »Wszelkie przeżycia są świadome«; specjalnie w odniesieniu do przeżyć intencjonalnych znaczy to zatem, że są nie tylko świadomością czegoś i jako ta świadomość istnieją nie tylko wtedy, gdy same są obiektami świadomości dokonującej refleksji, lecz i wtedy, gdy jeszcze nie są poddane refleksji, są już obecne jako »tło i tym samym jako zasadniczo gotowe do tego, by być spostrzeganymi, spostrzeganymi zrazu w sensie analogicznym jak rzeczy niezauważone w polu naszego widzenia zewnętrznego". Husserl, Idee czystej fenomenologii i fenomenologicznej filozofii, 134. 
byłaby świadomością dla przedmiotu - polega jej specyficzny sposób istnienia, jej absolutność i niezależność odnośnie do refleksji. Świadomość istnieje w taki sposób, że jest stale obecna w sobie samej"68. Dodajmy: absolutna świadomość jest stale, nietematycznie, przedrefleksyjnie (nieprzedmiotowo) dana sobie samej i stanowi byt niezobiektywizowany, anonimowo funkcjonujący, który zawsze wyprzedza refleksję rozumianą jako Nachgewahren, spostrzeganie następujące p o przeminięciu aktualnego przepływu przeżyć. Innymi słowy, świadomość poddana refleksji jest świadomościa, która dopiero co była anonimowa, toteż świadomość refleksyjnie zobiektywizowana nie jest pierwotną świadomością lecz odsyła do świadomości absolutnej w znaczeniu niezobiektywizowanej ${ }^{69}$. Chodzi w istocie o praimpresjonalną teraźniejszość strumienia przeżyć (pramodalną teraźniejszość), która jest obecna dla siebie w tym znaczeniu, że ma wprawdzie charakter świadomości wewnętrznej, Husserl mówi nawet: świadomości spostrzeżeniowej, ale nie $\mathrm{w}$ sensie spostrzegania immanentnego, uznającego $\mathrm{w}$ bycie swe przedmioty czy jakiejś wyższej prezentującej świadomości, lecz w znaczeniu praświadomości, w której przeżycia są nieprzedmiotowo, przedrefleksyjnie uświadamiane ${ }^{70}$ :

Każde przeżycie jest „doznane”, jest immanentnie „spostrzeżone” (świadomość wewnętrzna), choć naturalnie nie każde jest uznane w bycie, domniemane (spostrzegać nie znaczy tu domniemając być zwróconym ku [czemuś] i uchwytywać). [...] Każde "przeżycie” w ścisłym sensie jest wewnętrznie spostrzegane. Lecz świadomość wewnętrzna nie jest $\mathrm{w}$ tym samym sensie „przeżyciem”. Sama nie jest znów wewnętrznie spostrzegana $^{71}$.

Aktualne przeżycia posiadają tym samym absolutne, niepodważalne uznanie w bycie (Setzung) nie dlatego, że kierujemy na nie refleksję, ale dlatego, że są przedrefleksyjnie przeżywane w aktualnej, spostrzeżeniowej świadomości, zgodnie z zasadą że immanentne uznanie $\mathrm{w}$ bycie „należy istotowo do zawartości całej wewnętrznej (aktualnej) świadomości"72. Skoro świadomością tetyczną (ustalającą) w odniesieniu

${ }^{68}$ Lévinas, Théorie de l'intuition dans la phénoménologie de Husserl, 56.

${ }^{69}$ Zob. Edmund Husserl, Wykłady z fenomenologii wewnętrznej świadomości czasu, przeł. Janusz Sidorek (Warszawa: PWN, 1989), 110-111, 165; Piotr Łaciak, Anonimowość jako granica poznania w fenomenologii Edmunda Husserla (Katowice: Wydawnictwo Uniwersytetu Śląskiego, 2012), 273-306.

70 Zob. Husserl, Idee czystej fenomenologii i fenomenologicznej filozofii, 361-362.

${ }^{71}$ Husserl, Wykłady z fenomenologii wewnętrznej świadomości czasu, 195.

72 Edmund Husserl, „Phantasie, Bildbewusstsein, Erinnerung. Zur Phänomenologie der anschaulichen Vergegenwärtigungen. Texte aus dem Nachlass (1898-1925)", red. Eduard Marbach, w: Edmund Husserl, Gesammelte Werke, t. 23 (The Hague-Boston-London: Martinus Nijhoff, 1980), 337-338. 
do wszystkiego, co istnieje, okazuje się świadomość spostrzeżeniowa, a absolutna świadomość jest immanentnie, spostrzeżeniowo, acz przedrefleksyjnie (przed wszelkim uprzedmiotowieniem), dana sobie samej, to przysługuje jej istnienie absolutne, to znaczy istnienie nie jest jej przypisane przez jakąś dalszą ustalającą świadomość ${ }^{73}$. Husserl pisze wprost: „Jeśli [...] każda treść sama w sobie i z konieczności jest »praświadoma«, to pytanie o jakąś dalszą świadomość prezentującą jest pozbawione sen$\mathrm{su}^{\prime \prime 74}$. Na mocy tej przedrefleksyjno-spostrzeżeniowej obecności dla siebie absolutna świadomość jest świadomością bezwarunkowo samouznającą się w istnieniu, w języku Fichtego: Sich-Selbst- Setzen $^{75}$.

O absolutnej świadomości, poprzedzającej refleksyjną obiektywizację, możemy tylko powiedzieć, że jest, nie zaś jaka jest; jako taka, wyraża się w pierwotnym, egotycznym fakcie "Ja jestem”, stanowiącym granicę wszelkiego poznania oraz jego warunek ${ }^{76}$. "Ja jestem" nie oznacza jakiegoś stanu rzeczy, lecz jest faktem pierwotnym, a zarazem bezjakościowym. Jeżeli bowiem istnienie nie jest realnym orzecznikiem, to w odniesieniu do świadomości oznacza to, że mówiąc „Ja jestem", nie przypisuję własnemu Ja jakiejś realnej własności, lecz stwierdzam na podstawie przedrefleksyjnego doświadczenia apodyktycznie pewny fakt czystego, poprzedzającego wszelką istotę istnienia, fakt niedopuszczający dalszego pytania o rację. Husserl $\mathrm{w}$ ten sposób charakteryzuje ten absolutny fakt "Ja jestem": "Absolut ma w sobie samym swoją podstawę [...]. Jego konieczność nie jest koniecznością istotowa, która pozostawia miejsce dla tego, co przypadkowe. Wszelkie istotowe konieczności są momentami jego faktyczności, są sposobami jego funkcjonowania w odniesieniu

${ }^{73} \mathrm{~W}$ związku z problematyką istnienia tego, co immanentne, Danuta Gierulanka w przypisie do tłumaczenia Idei czystej fenomenologii i fenomenologicznej filozofii na język polski trafnie zwraca uwagę na to, że w odniesieniu do przeżyć świadomości transcendentalnej moment Setzung „należy uważać nie za jakiś odpowiednik uznania ich istnienia, uznania, które dokonywałoby się w świadomościowym akcie ich poznawania (a tym mniej fingowania), lecz za coś absolutnego, właściwego im samym dla siebie, bez względu na to, czy są np. poznawane, czy nie. Przeżycia te bowiem zdaniem Husserla - właśnie same stanowią sferę czystej świadomości, bytu absolutnego, a nie - jak ewentualnie przedmioty innych sfer - jedynie odpowiedniki przeżyć świadomych (intencyjnych)". Husserl, Idee czystej fenomenologii i fenomenologicznej filozofii, 9 (przypis tłumacza).

${ }_{74}$ Husserl, Wykłady z fenomenologii wewnętrznej świadomości czasu, s. 182.

75 Zob. Siemek, „Husserl i dziedzictwo filozofii transcendentalnej”, 274.

${ }^{76}$ Zob. Piotr Łaciak, „Absolutny fakt »Ja jestem « jako konsekwencja pierwszeństwa istnienia przed istotą", Archiwum Historii Filozofii i Myśli Społecznej 63 (2018): 101-116. 
do samego siebie - sposobami, $\mathrm{w}$ jakich rozumie on samego siebie lub może rozumieć" 77 .

\section{Wnioski}

Analiza sposobów dania doprowadziła Husserla do rozróżnienia zasadniczo odmiennych sposobów istnienia: świata i świadomości. Jeżeli chodzi o istnienie świata, to Husserl występuje przeciwko jego absolutyzacji przez naturalizm, wykazując, że istnienie świata wymaga stałego potwierdzania $w$ dalszym przebiegu doświadczenia. Skoro istnienie nie jest realnym orzecznikiem, w odniesieniu do świata podstawy istnienia nie należy upatrywać $\mathrm{w}$ obiektywnej rzeczywistości, lecz w specyficznym sposobie prezentacji w świadomości. Istnienie świata stanowi korelat przeświadczeniowej pewności uświadamianej w stale potwierdzającym się, jednozgodnym związku rzeczywistych i możliwych spostrzeżeń, a pewność ta ma charakter presumpcyjny i antycypuje na podstawie dotychczasowego doświadczenia jego dalszy przebieg, nie wykluczając możliwości zmiany tego przebiegu lub jego załamania się, to znaczy rozpłynięcia się doświadczeń w natłoku wrażeń. W konsekwencji świat z konieczności zakłada doświadczającą go (ustalającą) świadomość, a z presumpcyjnego, zasadniczo nieadekwatnego sposobu doświadczania świata można wnosić o jego relatywności ${ }^{78}$. Świat zatem nie tylko jest przeciwstawiony świadomości, lecz także z konieczności do niej odsyła, a świadomość aktualnie doświadczająca świata nie jest świadomością w ogóle, lecz ma strukturę określoną stosownie do zróżnicowania danych przedmiotów.

Doświadczenie, oczywistość, nie mają charakteru pustej ogólności, lecz różnicują się odpowiednio do rodzajów, gatunków i kategorii dziedzinowych tego, co istnieje, a także ze względu na wszelkiego rodzaju modalności czasoprzestrzenne. To, co istnieje, $\mathrm{w}$ jakimkolwiek sensie, konkretnym lub abstrakcyjnym, realnym bądź idealnym, ma własne sposoby samoprezentacji, a po stronie Ja - swoje rodzaje intencji w modi obowiązywania i należące do nich rodzaje subiektywnych przemian obowiązywania w syntezach zgodności i niezgodności jednopodmiotowej i intersubiektywnej ${ }^{79}$.

77 Edmund Husserl, „Zur Phänomenologie der Intersubjektivität. Texte aus dem Nachlass", cz. 3: 1929-1935, red. Iso Kern, w: Edmund Husserl, Gesammelte Werke, t. 15 (Den Haag: Martinus Nijhoff, 1973), 386.

78 Zob. Kern, Husserl und Kant, 279-283.

${ }^{79}$ Husserl, „Krisis der europäischen Wissenschaften und die transzendentale Phänomenologie", 169. Cyt. za polskim przekładem fragmentów Kryzysu... - E. Husserl, „Wybór pism”, 182. 
Sama świadomość konstytuująca świat jest dana w swym istnieniu absolutnie i źródłowo zgodnie z zasada, że „moja aktualność przeżyciowa jest absolutną rzeczywistościa, daną przez bezwarunkowe, w ogóle niedające się podważyć uznanie w bycie (Setzung)" ${ }^{\prime 80}$. Poddając analizie sposób dania świadomości, Husserl przeciwstawia spostrzeżeniu transcendentnemu, to znaczy spostrzeżeniu rzeczy, spostrzeżenie immanentne, to znaczy refleksję, w której przeżycia są ujęte aktowo, apodyktycznie i zasadniczo adekwatnie jako istniejące przedmioty, ale świadomość nie zawdzięcza swego istnienia zawartemu w spostrzeżeniu immanentnym (refleksji) uznaniu w bycie, ponieważ istnieje koniecznie również wtedy, gdy nie jest poddawana refleksji. Aktualnie doświadczająca świadomość jest źródłem wykazywania istnienia wszelkiego bytu transcendentnego, ale sama nie wymaga takiego wykazywania, jako że jest absolutną rzeczywistością która posiada w s obie niepodważalne uznanie istnienia, bez względu na to, czy jest poddawana refleksji, czy też nie. Innymi słowy, absolutna świadomość jako sfera pierwotnego samodania, przed wszelkim uprzedmiotowieniem, jest świadomością bezwarunkowo samouznającą się w istnieniu, dlatego nie wymaga dalszej źródłowo prezentującej (tetycznej) świadomości, w której byłaby dana. Mówiąc o absolutnym istnieniu mojej świadomości, Husserl ma na uwadze przedrefleksyjnie przeżywany fakt doświadczenia "Ja jestem", fakt pierwotny, poprzedzający i warunkujący wszelką refleksyjną obiektywizację. Ponieważ istnienie nie jest realnym orzecznikiem, przeto absolutny fakt "Ja jestem" okazuje się faktem czystego, bezjakościowego istnienia (Sein), faktem „że jestem”, którego nie można wyprowadzić z zasadniczo przypadkowej treściowej zawartości (Sosein) mojego strumienia przeżyćs1.

\section{Bibliografia}

Husserl Edmund. 1979. „Aufsätze und Rezensionen (1890-1910)”, red. Bernhard Rang. W: Edmund Husserl, Gesammelte Werke. T. 22. The Hague-Boston-London: Martinus Nijhoff.

Husserl Edmund. 2000. Badania logiczne. T. 2, cz. 1: Badania dotyczace fenomenologii i teorii poznania, przeł. Janusz Sidorek. Warszawa: PWN.

Husserl Edmund. 2000. Badania logiczne. T. 2, cz. 2: Badania dotyczace fenomenologii i teorii poznania, przeł. Janusz Sidorek. Warszawa: PWN.

Husserl Edmund. 1962. „Die Krisis der europäischen Wissenschaften und die transzendentale Phänomenologie. Eine Einleitung in die phänome-

${ }^{80}$ Husserl, Idee czystej fenomenologii i fenomenologicznej filozofii, 138

81 Zob. Husserl, "Zur Phänomenologie der Intersubjektivität. Texte aus dem Nachlass", cz. 2: 1921-1928, 151-158. 
nologische Philosophie", red. Walter Biemel. W: Edmund Husserl, Gesammelte Werke. T. 6. Den Haag: Martinus Nijhoff.

Husserl Edmund. 1973. „Ding und Raum. Vorlesungen 1907”, red. Ulrich Claesges. W: Edmund Husserl, Gesammelte Werke. T. 16. Den Haag: Martinus Nijhoff.

Husserl Edmund. 2013. Doświadczenie i sąd. Badania nad genealogia logiki, przeł. Bogdan Baran. Warszawa: Fundacja Aletheia.

Husserl Edmund. 1959. „Erste Philosophie (1923/24)”, cz. 2: „Theorie der phänomenologischen Reduktion", red. Rudolf Boehm. W: Edmund Husserl, Gesammelte Werke. T. 8. Den Haag: Martinus Nijhoff.

Husserl Edmund. 1987. „Fenomenologia i antropologia”, przeł. Sławomira Walczewska. Archiwum Historii Filozofii i Myśli Społecznej 32: 333-346.

Husserl Edmund. 1992. Filozofia jako ścisła nauka, przeł. Włodzimierz Galewicz. Warszawa: Fundacja Aletheia.

Husserl Edmund. 1990. Idea fenomenologii. Pięć wykładów, przeł. Janusz Sidorek. Warszawa: PWN.

Husserl Edmund. 1975. Idee czystej fenomenologii i fenomenologicznej filozofii. Księga pierwsza, przeł. Danuta Gierulanka. Warszawa: PWN.

Husserl Edmund. 1982. Medytacje kartezjańskie, przeł. Andrzej Wajs. Warszawa: PWN.

Husserl Edmund. 1980. „Phantasie, Bildbewusstsein, Erinnerung. Zur Phänomenologie der anschaulichen Vergegenwärtigungen. Texte aus dem Nachlass (1898-1925)", red. Eduard Marbach. W: Edmund Husserl, Gesammelte Werke. T. 23. The Hague-Boston-London: Martinus Nijhoff.

Husserl Edmund. 1993. „Wybór pism”, przeł. Sławomira Walczewska. W: Krystyna Święcicka, Husserl. 123-195. Warszawa: Wiedza Powszechna.

Husserl Edmund. 1989. Wykłady z fenomenologii wewnętrznej świadomości czasu, przeł. Janusz Sidorek. Warszawa: PWN.

Husserl Edmund. 1973. „Zur Phänomenologie der Intersubjektivität. Texte aus dem Nachlass", cz. 2: 1921-1928, red. Iso Kern. W: Edmund Husserl, Gesammelte Werke. T. 14. Den Haag: Martinus Nijhoff.

Husserl Edmund. 1973. „Zur Phänomenologie der Intersubjektivität. Texte aus dem Nachlass", cz. 3: 1929-1935, red. Iso Kern. W: Edmund Husserl, Gesammelte Werke. T. 15. Den Haag: Martinus Nijhoff.

Kant Immanuel. 2010. „Jedyna możliwa podstawa dowodu na istnienie Boga", przeł. Translatorium Filozofii Niemieckiej Instytutu Filozofii UMK pod kierunkiem Mirosława Żelaznego. W: Immanuel Kant, Dzieła zebrane, t. 1: Pisma przedkrytyczne, red. Marek Jankowski, Tomasz Kupś, 527-614. Toruń: Wydawnictwo Naukowe UMK.

Kant Immanuel. 2001. Krytyka czystego rozumu, przeł. Roman Ingarden. Kęty: Wydawnictwo ANTYK.

Kern Iso. 1964. Husserl und Kant. Eine Untersuchung über Husserls Verhältnis zu Kant und zum Neukantianismus. Den Haag: Martinus Nijhoff.

Landgrebe Ludwig. 1963. „Seinsregionen und regionale Ontologien in Husserls Phänomenologie". W: Ludwig Landgrebe, Der Weg der Phänome- 
nologie. Das Problem einer ursprünglichen Erfahrung. 143-162. Gütersloh: Gütersloher Verlagshaus Gerd Mohn.

Lévinas Emmanuel. 1994. Théorie de l'intuition dans la phénoménologie de Husserl. Paris: Librairie Philosophique J. Vrin.

Łaciak Piotr. 2018. „Absolutny fakt "Ja jestem« jako konsekwencja pierwszeństwa istnienia przed istotą". Archiwum Historii Filozofii i Myśli Społecznej 63: 101-116.

Łaciak Piotr. 2012. Anonimowość jako granica poznania w fenomenologii Edmunda Husserla. Katowice: Wydawnictwo Uniwersytetu Śląskiego.

Rang Bernhard. 1979. „Einleitung des Herausgebers”. W: Edmund Husserl, "Aufsätze und Rezensionen (1890-1910)", red. Bernhard Rang, IX-LVI. W: Edmund Husserl, Gesammelte Werke. T. 22. The Hague-Boston-London: Martinus Nijhoff.

Rang Bernhard. 1973. Kausalität und Motivation. Untersuchungen zum Verhältnis von Perspektivität und Objektivität in der Phänomenologie Edmund Husserls. Den Haag: Martinus Nijhoff.

Siemek Marek J. 1994. „Husserl i dziedzictwo filozofii transcendentalnej”. W: Filozofia transcendentalna a dialektyka, red. Marek J. Siemek, 265-286. Warszawa: Oficyna Naukowa.

Ströker Elisabeth. 1987. „Intentionalität und Konstitution. Wandlungen des Intentionalitätskonzepts in der Philosophie Husserls". W: Elisabeth Ströker, Phänomenologische Studien. 54-74. Frankfurt am Main: Vittorio Klostermann.

Zahavi Dan. 1992. Intentionalität und Konstitution. Eine Einführung in Husserls "Logische Untersuchungen". University of Copenhagen: Museum Tusculanum Press.

\section{Streszczenie}

W analogii do Kanta Husserl twierdzi, że istnienie nie jest realnym orzecznikiem, co oznacza, że istnienie przedmiotu nie polega na jego odniesieniu do obiektywnej rzeczywistości, lecz raczej na specyficznym sposobie dania W świadomości. W konsekwencji pojęcie istnienia jest rozumiane odnośnie do różnych sposobów prezentacji (Gegenwärtigung) rzeczywistości i może być rozjaśnione tylko $\mathrm{w}$ czysto fenomenologicznym opisie naocznych sposobów jej dania. Celem badania fenomenologicznego jest rozjaśnienie sensu realnego istnienia transcendentnych rzeczy, w szczególności uprawnienia generalnej tezy nastawienia naturalnego jako uniwersalnego przeświadczenia, w którym uświadamiamy sobie istnienie świata. To rozjaśnienie zakłada konstytuującą świadomość jako pierwotnie miejsce wykazywania sensu istnienia, tak że istnienie transcendentnych rzeczy zawsze odsyła do aktualnie doświadczającej świadomości, w której takie rzeczy są dane. Istnienie realnego świata jest zatem relatywne $\mathrm{w}$ odniesieniu do istnienia świadomości konstytuującej świat, która jest rozumiana jako sfera absolutnego samodania, ponieważ nie odsyła w swym istnieniu do jakiejś wyższej świadomości, w której byłaby dana. To implikuje, że istnienie realnego świata ma presumpcyjny charakter, jako że jest korelatem gen- 
eralnej tezy nastawienia naturalnego, która wymaga potwierdzenia w dalszym przebiegu doświadczenia, podczas gdy aktualnie doświadczająca świadomość stanowi absolutną sferę bytowa, która jest dana w oczywistości apodyktycznej i ustanawia się sama przez się $\mathrm{w}$ istnieniu.

Słowa kluczowe: Edmund Husserl, Immanuel Kant, istnienie, krytyka poznania, świadomość, świat

\section{The Clarification of the Sense of Existence as an Aim of Husserl's Phenomenology}

\section{Summary}

In analogy to Kant, Husserl argues that existence is not a real predicate, that is to say that the existence of an object consists in not its reference to objective reality but rather in the specific manner of givenness in consciousness. As a consequence, the concept of existence is understood with regard to the different ways of presentation (Gegenwärtigung) of reality, and it can only be clarified in a pure phenomenological description of intuitive modes of its givenness. The aim of phenomenological investigation is to clarify the sense of real existence of transcendent things, in particular, the legitimacy of the general thesis of the natural attitude as universal belief in which is realized the existence of the world. This clarification presupposes the constituting consciousness as an original place of the demonstration of the sense of the existence so that the existence of the transcendent things always refers to the actually experiencing consciousness in which such things are given. Thus, the existence of the real world is relative to the existence of world-constituting consciousness that is understood as a sphere of absolute self-givenness because it does not refer in its existence to a higher consciousness in which it would be given. This implies that the existence of the real world has presumptive character, as it is a correlate of the general thesis of the natural attitude, which requires the confirmation in the further course of the experience, whereas the actually experiencing consciousness is an absolute sphere of being that is given in apodictic evidence and it posits itself through itself in existence.

Keywords: Edmund Husserl, Immanuel Kant, existence, critique of knowledge, consciousness, world 